\title{
PEDRO AMÉRICO E O NACIONALISMO ROMÂNTICO CONSERVADOR
}

\author{
Lúcio Flávio Vasconcelos ${ }^{1}$
}

\section{Introdução}

Pedro Américo foi o pintor mais representativo da arte palaciana $e$ do nacionalismo romântico conservador ${ }^{2}$ brasileiro no século XIX. No decorrer da sua atribulada vida, exerceu múltiplos ofícios. Foi filósofo, romancista, ensaísta, poeta, desenhista, caricaturista, político e agente do exército francês. Em algumas dessas profissões ele obteve maior destaque. Em outras foi um tanto quanto obscuro ${ }^{3}$.

Mas foi como pintor que ele atingiu a consagração artística e o reconhecimento social. Nenhum outro artista no Brasil imperial alcançou tamanha notoriedade nacional e expressão internacional. Suas pinturas históricas atraíam multidões às exposições e ajudaram a consolidar o poder monárquico de D. Pedro II durante seu longo reinado, que se prolongou por 49 anos.

As telas de Pedro Américo que retratam a Guerra do Paraguai (1864-1870) ${ }^{4}$ impressionam pela grandiosidade, perfeccionismo e impacto visual. Além disso, contribuiu para aumentar o prestígio político do exército brasileiro. Por meio das suas pinturas históricas de cunho cívico, o nacionalismo forjado no Paço Imperial ganhou expressão artística, auxiliou a estruturar o Estado brasileiro e se cristalizou no imaginário popular. Seu quadro mais famoso, Proclamação da Independência (1888), passou a fazer parte da formação cultural e política de várias gerações e é reconhecido por todos os brasileiros minimamente letrados.

Dessa forma, foi como pintor histórico que Pedro Américo se destacou artística e socialmente. São as cenas de batalha retratadas que lhe deram fama nacional $e$ destaque internacional. Os combates acirrados, o clima de violência, a fumaça das explosões, o embate renhido entre os soldados, o heroísmo patriótico, o sofrimento dos feridos, o terror dos animais, o absurdo da morte. Esse é o cenário vívido em cores e sangue, apaixonadamente retratados pelo artista em grandiosos painéis.

\footnotetext{
${ }^{1}$ Doutor em História Social pela Universidade de São Paulo. Professor Associado do Departamento de História da Universidade Federal da Paraíba. E-Mail: <lucioflaviovasconcelos@yahoo.com>.

2 "O romantismo conservador stricto sensu manifesta-se, sobretudo, na obra de pensadores políticos, propriamente ditos, que legitimam a ordem estabelecida como resultado 'natural' da evolução histórica. Por exemplo: a Escola Histórica do Direito (V. Hugo, Savigny); a filosofia positiva do Estado, de Friedrich Julius Stahl; a ideologia tory de um Disrael. Entre os grandes filósofos do romantismo, é provavelmente Schelling quem mais se aproxima dessa posição e, na economia política, Malthus não deixa de ter laços com ela". SAYRE, Robert \& LÖWY, Michael. Romantismo e política. Tradução de Eloísa de Araújo Oliveira. Rio de Janeiro: Paz e Terra, 1993, p. 46-47.

${ }^{3}$ OLIVEIRA, J. M. Cardoso. Pedro Américo, sua vida e suas obras. Rio de Janeiro: Senado Federal, 1943, p. 18.

${ }^{4}$ As telas que abordam a Guerra do Paraguai são: Passagem do Chaco (1871), Batalha de Campo Grande (1871) e Batalha do Avaí (1877).
} 
Pedro Américo nasceu de uma família sem posses, na cidade de Areia, interior da província da Paraíba, em 29 de abril de 1843. Filho de um pequeno comerciante, sua trajetória de vida é fulgurante do ponto de vista da ascensão social. Ainda criança partiu do brejo paraibano e trilhou todos os caminhos possíveis, até alcançar a posição de pintor consagrado. Sem o apoio institucional do monarca D. Pedro II, seu talento artístico e intelectual não teria sido lapidado nas melhores academias do mundo: primeiro no Rio de Janeiro, depois em Paris, em seguida Bruxelas e, por último, Florença. Sem as obras de Pedro Américo, o Império brasileiro não teria encontrado seu mais expressivo intérprete artístico.

Pedro Américo foi influenciado decisivamente pelo romantismo, movimento político, cultural e artístico predominante no século XIX ${ }^{5}$. Esse também foi um século extremamente conturbado, convulsionado pelo surgimento do movimento operário, abalado por revoluções e reações conservadoras ${ }^{6}$. Ao longo dos turbulentos anos de formação dos Estados nacionais, a Europa foi palco de contendas políticas monumentais, consequência das lutas entre os países em expansão e conflitos internos fraticidas.

O processo de estruturação da nação brasileira não foi exceção. Por todo o século $\mathrm{XIX}$, vários conflitos internos assolaram as províncias e guerras internacionais ameaçaram a integridade territorial. Única monarquia num continente republicano, o Império brasileiro passou por agitações sociais e crises políticas que ameaçavam sua fragilidade institucional. Além disso, a longevidade do regime escravista distanciou paulatinamente o Brasil das demais nações latino-americanas em formação ${ }^{7}$.

Para se firmar perante o país, cabia ao Estado imperial realizar propaganda nacionalista permanente que criasse uma identidade entre a monarquia $e$ a população. O elo era centrado na figura do imperador D. Pedro II. Antecipada sua maior idade aos 14 anos, D. Pedro II estava consciente dos desafios para consolidarse perante as elites provinciais como seu legítimo representante e condutor da nação ${ }^{8}$.

No país em que, de acordo com o censo realizado em $1872,77 \%$ da população era constituída por pessoas que não sabiam nem ler nem escrever, seria fundamental a utilização de imagens grandiosas para disciplinar o comportamento social, difundir a religião cristã e expandir a ideologia política nacionalista. Por essa razão, a pintura histórica foi largamente empregada pelo império para consolidar o projeto de nação elaborado pelo grupo palaciano.

Nessa estratégia de poder, a Academia Imperial de Belas Artes desempenhou papel central. Por seus bancos escolares passaram dezenas de jovens de diferentes províncias que obtiveram sólida formação artística e retrataram um país idealizado, tão necessário ao projeto de nação elaborado pelos intelectuais e artistas influenciados pelo romantismo. Entre eles se destacaram Manuel de Araújo Porto Alegre, Victor Meirelles, Rodolfo Amodeo, Henrique Bernardelli e Pedro Américo.

\footnotetext{
${ }^{5}$ GUINSBURG, J. "Romantismo, historicismo e história". In: GUINSBURG, J. (org.). Romantismo. 3. ed. São Paulo: Perspectiva, 2011, p. 13-21.

${ }^{6}$ MAYER, Arno J. A força da tradição. São Paulo: Companhia das Letras, 1987, p. 133-186.

${ }^{7}$ BETHELL, Leslie \& CARVALHO, José Murilo de. "O Brasil, da Independência a meados do século XIX”. In: BETHEL, Leslie. História da América - Vol. III. São Paulo: EDUSP, 2001, p. 695-768.

${ }^{8}$ CARVALHO, José Murilo de. D. Pedro II. São Paulo: Companhia das Letras, 2007, p. 38.
} 
Numa nação em formação, em que o mercado privado de artes era praticamente inexistente, cabia ao governo imperial o subsídio necessário para formação $e$ manutenção desse grupo de artistas. Inegavelmente, sem a proteção estatal, não existiria a profusão de pinturas históricas que ajudaram na edificação e consolidação do ideário nacionalista.

Neste artigo abordaremos o conflituoso contexto histórico em que ocorreu a trajetória artística, intelectual e política de Pedro Américo e sua contribuição ao projeto de nação liderado por D. Pedro II. Seguidor do nacionalismo romântico conservador, Pedro Américo transitou, sem maiores percalços, entre liberais $e$ conservadores, monarquistas e republicanos, católicos e maçons, escravistas e emancipacionistas, e ajudou a consolidar o poder monárquico através de suas obras artísticas monumentais.

\section{Papel Estratégico da Academia Imperial de Belas Artes}

A Academia Imperial de Belas Artes nasceu da proposta da Missão Artística Francesa, que aportou na colônia em 26 de março de 1816. Após a derrocada de Napoleão Bonaparte, em 1815, o rei D. João VI reatou relações diplomáticas com a França, referência artística mundial. No intuito de promover a arte palaciana no Brasil, a Corte do Rio de Janeiro entrou em contato com Joachim Lebreton, que havia colaborado estreitamente com o regime bonapartista, caindo em desgraça após a restauração monárquica na França. Seu papel seria chefiar a Missão Artística em território brasileiro. Prontamente, Lebreton reuniu um grupo de pintores e escultores $e$ rumou para o Brasil.

O estilo artístico que a Missão Francesa vai desenvolver no Brasil é o Neoclassicismo. Imbuído do ideário Iluminista, que pregava o fim do predomínio da Igreja Católica na vida secular $e$ a desmistificação das superstições e dogmas religiosos, o Neoclassicismo se mirava nos exemplos da cultura greco-romana.

No projeto nacionalista brasileiro, implantado a partir da década de 1840 por D. Pedro II, a Academia Imperial de Belas Artes, o Instituto Histórico e Geográfico Brasileiro (IHGB) e o Colégio Pedro II desempenharam papéis estratégicos na concepção de nação, formulado pelo monarca e seu grupo palaciano. Esse projeto era fundamentado numa idealização do indígena e da natureza exuberante e pródiga dos trópicos ${ }^{9}$.

Semelhante ao tratamento que o imperador dispensava ao IHGB, estabelecendo premiações e incentivos financeiros para os trabalhos historiográficos sobre o Brasil, D. Pedro II passou a instituir prêmios e comendas aos alunos que se destacassem nos cursos ofertados pela Academia. Além disso, bolsas de estudos foram dadas para que aprimorassem seus conhecimentos no exterior. Em poucos anos, sua imagem de reifilósofo e mecenas das artes se projetara por todo o Império.

Em 1854, ano anterior ao ingresso de Pedro Américo na Academia, havia assumido um novo diretor da instituição: Manuel de Araújo Porto Alegre, futuro barão de Santo Ângelo. Pintor, arquiteto, poeta, caricaturista, crítico de arte,

\footnotetext{
${ }^{9}$ SCHWARCZ, Lilia Moritz. As barbas do imperador: D. Pedro II, um monarca nos Trópicos. São Paulo: Companhia das Letras, 1998, p. 38-49.
} 
historiador, jornalista, romancista, professor, político e diplomata, Araújo Porto Alegre foi um dos mais versáteis homens do Império e um dos maiores divulgadores do romantismo na segunda metade do século XIX ${ }^{10}$. Sua importância intelectual para o projeto nacionalista foi decisiva. Sua influência sobre a carreira de Pedro Américo foi determinante.

De origem pobre, nascido em Rio Pardo, pequena cidade do Rio Grande do Sul, Araújo Porto Alegre mudou-se para o Rio de Janeiro em 1827, com o objetivo de estudar. Chegando à capital do Império, decidiu se inscrever na recém-inaugurada Academia Imperial de Belas Artes. Foi aluno de Jean Baptiste Debret, do qual se tornou amigo.

Ao terminar o curso com louvor, Porto Alegre partiu para complementar seu aprendizado na École Nationale Supérieure des Beaux-Arts, em Paris. Aproveitou sua permanência na Europa e viajou pelo interior da Itália, Bélgica, Holanda e Inglaterra. Após o périplo de aperfeiçoamento artístico, retornou ao Brasil em 1837, passando a lecionar desenho na Academia Imperial de Belas Artes.

Sendo um dos maiores representantes do romantismo no Brasil, Araújo Porto Alegre seguiu seus cânones: exaltar a natureza e tentar consolidar uma cultura própria, em relativa autonomia do continente europeu. A flora, a fauna e os índios brasileiros passaram por um processo de mitificação em busca de elementos constitutivos da identidade nacional.

Sempre em conformidade com as diretrizes do romantismo, as pinturas de Araújo Porto Alegre se expressavam nos grandes feitos do passado e do presente imperial, como também na exaltação luxuriante da natureza tropical. Quando assumiu a cadeira de professor da Academia, Porto Alegre passou a defender que os exercícios de desenho realizados pelos estudantes deveriam retratar a fauna e a flora americanas, e não apenas reproduzir as paisagens europeias, como era o costume. Para ele, a valorização da nação deveria nortear a arte.

$\mathrm{Na}$ sua monumental obra Floresta Brasileira, de 1853, Araújo Porto Alegre demonstra toda força, beleza e magnitude da flora tropical. Nesse mesmo ano, por entrar em choque com o pintor Félix-Emile Taunay, então diretor da Academia Imperial de Belas Artes, Porto Alegre pediu demissão do cargo de professor e passou à ofensiva, se posicionando contra o tradicionalismo que norteava o ensino das artes no Brasil.

Em carta ao imperador D. Pedro II, Araújo Porto Alegre propôs reforma imediata na estrutura curricular da Academia. Nela, indicava a necessidade da vinculação explícita entre a produção artística e o governo imperial, no sentido de consolidar o projeto nacionalista centrado num Estado forte. Diz a carta:

Para que as artes comecem a ter uma vida regular $e$ floresçam pouco a pouco, para que elas espalhem o seu benigno insuflo na moral pública, e na indústria, é necessário

${ }^{10}$ SQUEFF, Letícia. O Brasil nas letras de um pintor: Manuel de Araújo Porto-Alegre (1806-1879). Campinas: Editora da UNICAMP, 2004, p. 169-204. 
que a família artística tenha um ponto de constante apoio no país, e este ponto é o Governo. ${ }^{11}$

Dois anos depois, em 1855, Manuel Araújo Porto Alegre venceu a disputa com Taunay. D. Pedro II passou a considerá-lo estratégico na condução de uma política artística voltada para a consolidação da nação. Araújo Porto Alegre foi nomeado diretor da Academia Imperial de Belas Artes e começou a colocar em prática seu projeto de ensino voltado para a edificação do Império, personalizado na figura do monarca. É nessa Academia, de forte viés nacionalista, que Pedro Américo terá o aprendizado sistemático de pintura.

\section{Formação Artística e Política de Pedro Américo}

Tendo convencido o imperador do seu talento através de cartas de importantes políticos, Pedro Américo conseguiu matricular-se na Academia Imperial de Belas Artes e passou a frequentá-la no começo de $1855^{12}$. A fiscalização pedagógica sobre os alunos era rigorosa. Relatórios sistemáticos sobre o progresso dos estudantes eram remetidos ao próprio imperador. Como aluno bolsista do Império, Pedro Américo deveria ter um comportamento exemplar.

Como a maioria dos alunos que frequentavam a Academia era formada por jovens de origem pobre, a vigilância era redobrada. Qualquer deslize mais grave era punido com a expulsão. As exigências sobre Pedro Américo foram enormes. Enquanto frequentava a Academia, estudava no Colégio Pedro II. Ao concluir seu curso, obteria o título de bacharel em letras, que o credenciaria a ingressar em qualquer faculdade do Brasil.

O rigor de estudos na Academia era absoluto. No seu período de aprendizagem, Pedro Américo frequentou os cursos de matemática, anatomia, desenho geométrico, estudo sistemático de modelos, reprodução de paisagem e pintura histórica, carrochefe do neoclassicismo. O objetivo era o aprimoramento técnico do estudante que, unido ao dom artístico, desenvolveria o talento e o transformaria num autêntico e vigoroso pintor ${ }^{13}$.

Em carta a Brunnet, datada de 20 de fevereiro de 1857, Pedro Américo descreve seu ano acadêmico e já manifesta interesse em se aperfeiçoar em pintura histórica. Além disso, num lampejo de vaidade, revela orgulho por se destacar em meio a colegas mais velhos.

[...] fiz exames no dia 26 de setembro perante o imperador, o Sr. Ministro do Império e outros do corpo Acadêmico e tirei duas medalhas de prata e uma de ouro, pelo meu exame $e$

\footnotetext{
${ }^{11}$ PORTO-ALEGRE apud MATTOS, Claudia Valladão de. "Imagem e palavra". In: O Brado do Ipiranga. São Paulo: EDUSP, 1999, p. 83.

${ }^{12}$ MELLO JÚNIOR, Donato. Pedro Américo de Figueiredo e Melo (1843-1905). Rio de Janeiro: Pinakotheke, 1983, p. 25-30.

${ }^{13}$ ZACCARA, Madalena. Pedro Américo: um artista brasileiro do século XIX. Recife: Editora Universitária da UFPE, 2011, p. 45-68.
} 
trabalhos, a de ouro é o primeiro prêmio. Há na Academia 50 ou pouco mais alunos, há homens que estão há 15 anos estudando na Academia, e ainda estavam o ano passado no primeiro ano, tais são os Sres. Carmello, Guimarães e outros, parece incrível! Tenho vontade de seguir a pintura histórica, não sei se faço bem. ${ }^{14}$

Pedro Américo estava ciente de que seu desempenho escolar e artístico seria a plataforma para sua ascensão. No intuito de seguir os mesmos passos do diretor Araújo Porto Alegre, e apostando na possibilidade de complementar sua formação em Paris, Pedro Américo passou a se dedicar mais ainda aos estudos. Seus esforços foram recompensados. Muitos anos depois, em carta enviada em 1881 a Antônio Nicolau Tolentino, então diretor da Academia Imperial de Belas Artes, Pedro Américo afirmou que, ao longo do curso na Academia, ganhou doze medalhas de prata e três medalhas de ouro ${ }^{15}$.

Em 1858, aos quinze anos de idade, Pedro Américo havia terminado, simultaneamente, os cursos do Colégio Pedro II e da Academia Imperial de Belas Artes. Convicto do seu potencial intelectual e talento artístico, o jovem pintor planejou meticulosamente seu próximo projeto: estudar na prestigiadíssima École Supérieure des Beaux-Arts, em Paris. Com financiamento do governo imperial, Pedro Américo seguiu para a França.

Quando Pedro Américo chegou a Paris, em maio de 1859, o II Império vivenciava seu apogeu. O Museu do Louvre se tornara lugar de peregrinação para aqueles que queriam ter acesso às famosas obras de arte. Os cafés, pontos de encontro entre intelectuais, artistas e revolucionários, fervilhavam de ideias inovadoras. Todos os pintores que almejavam fama, sucesso e dinheiro sonhavam estudar na prestigiada École Superieure des Beaux Arts.

Na primeira metade do século XIX, Paris havia se transformado no epicentro das revoluções políticas e vanguardas artísticas do Ocidente. A partir da Revolução de 1789 , as ideias liberais e nacionalistas começaram a ganhar cada vez mais espaço no cenário político internacional. Com as Guerras Napoleônicas, que ocorreram entre 1799 e 1815, de profundas repercussões na Europa e América Latina, a cultura francesa se tornou referência obrigatória para os membros das elites do mundo inteiro. Vanguardas políticas e ideias conservadoras se digladiavam em constantes $e$ violentos embates ${ }^{16}$.

A primeira ação de Pedro Américo na capital francesa foi procurar o pintor Léon Cogniet. Sem a sua aceitação para orientá-lo, não poderia se inscrever na École des Beaux Arts. Léon Cogniet foi um dos maiores expoentes do Romantismo francês. Dedicou-se a pintura histórica e a composição de retratos de estadistas e generais.

${ }^{14}$ AMÉRICO apud TORRES, Tancredo. Pedro Américo. Natal: Fundação Guimarães Duque, 2001, p. 68.

${ }^{15}$ AMÉRICO apud ZACCARA, Pedro Américo..., p. 42.

${ }^{16}$ HOBSBAWM, Eric. Nações e nacionalismo desde 1780: programa, mito e realidade. Tradução de Maria Célia Paoli e Anna Maria Quirino. Rio de Janeiro: Paz e Terra, 1990, p. 27-61. 
Seu patriotismo exacerbado terá papel fundamental na formação nacionalista de Pedro Américo.

Autor das famosas telas A Guarda Nacional de Paris em Seu Caminho para o Exército; Tintoretto Pinta sua Filha Morta, Cenas de Julho de 1830 e A Expedição Egípcia Sob o Comando de Bonaparte, Léon Cogniet foi consagrado pela exaltação nacionalista dos feitos heroicos do exército francês. Após a leitura das cartas de recomendação, Cogniet aceitou orientá-lo. Sua influência sobre ele foi decisiva. Isso ficou claramente demonstrado quando Pedro Américo optou pela pintura histórica.

Entre os intelectuais franceses com que Pedro Américo entrou em contato na França, o pensador Victor Cousin foi aquele de maior influência na sua formação filosófica e política ${ }^{17}$. Filósofo, historiador e político, Cousin gozava de grande prestígio na Paris da segunda metade do Oitocentos. Partidário do Ecletismo filosófico ${ }^{18}$, afirmava que a Filosofia deveria separar o falso do verdadeiro existente nas várias correntes filosóficas. Na sua concepção, só aproximando os preceitos verídicos dos diversos ramos do pensamento se poderia formular um todo autêntico.

Combatendo as concepções materialistas que ganhavam força política, principalmente pela expansão do socialismo e do positivismo, Victor Cousin tentou fazer a junção entre as correntes filosóficas do idealismo hegeliano, sensualismo, misticismo e ceticismo. Seu tratado mais notável foi: Introducion à l'Histoire de la Philosophie $(1828)^{19}$. As leituras de suas obras marcaram definitivamente a formação intelectual de Pedro Américo e despertaram nele o sentimento antipositivista que manterá até o fim da sua vida.

Em 1862, Pedro Américo concluiu seus estudos na École des Beaux Arts. Mas relutava em retornar ao Brasil. Acreditava que tinha ainda muito a aprender no continente europeu. Em carta ao imperador Pedro II, datada de 6 de janeiro, ele informava ao monarca sobre a amplitude dos seus estudos.

Além dos meus trabalhos de pintura, que absorvem a maior parte do tempo, não esqueço um só instante as Ciências, que formam a base de todos os conhecimentos [...]. Para prova do meu aproveitamento quanto aos estudos científicos, passei com excelentes notas nos exames do Bacharelado em Ciências Físicas e Naturais, na Academia de Paris. Comecei a parte literária e matemática do Bacharelado em Ciências completo, e não terei uma prova dessa segunda parte, se tiver a infelicidade de regressar em maio próximo. ${ }^{20}$

${ }^{17}$ OLIVEIRA, Pedro Américo, sua vida...

${ }^{18}$ ABBAGNANO, Nicola. "Ecletismo" [verbete]. Dicionário de filosofia. São Paulo: Martins Fontes, 2007, p. 350 .

19 "Sua concepção é fortemente marcada pela influência de Hegel. Depois de definir o povo com base numa unidade ideal, a do Espírito, do Ser em uma unicidade, ele explica que o grande homem é a encarnação disso e participa, como indivíduo, de seu espírito. Victor Cousin deduz, pois, daí, a necessidade do grande homem, afirmando ao mesmo tempo que 'excesso e carência de individualidade matam igualmente o grande homem". DOSSE, François. O desafio biográfico: escrever uma vida. Tradução de Gilson César Cardoso de Souza. São Paulo: EDUSP, 2009, p. 174.

${ }^{20}$ AMÉRICO apud TORRES, Pedro Américo..., p. 73-74. 
O jovem pintor, sedento de conhecimento e apaixonado pela Europa, desejava permanecer na França para aprofundar os estudos e ampliar sua cultura.

Nesse mesmo ano, Pedro Américo revelou seu engajamento político nacionalista, que até então permanecera oculto. Intencionalmente polêmico, envolveu-se numa contenda internacional. Começara a chegar a Paris notícias de que o Brasil estava numa séria disputa com a Inglaterra, conflito que passou a ser denominado de Questão Christie, nome do embaixador britânico no Brasil: William Dougal Christie.

Em abril de 1862, o governo britânico enviou uma canhoneira para atacar a cidade gaúcha de Rio Grande. Em dezembro do mesmo ano, uma esquadra de guerra da marinha inglesa apreendeu cinco navios brasileiros e bloqueou o porto do Rio de Janeiro. Para suspender o cerco, exigia do governo imperial uma indenização de 3,2 mil libras esterlinas, em compensação pelo saque ao navio mercante britânico Prince of Wales, ocorrido em 1861, no litoral do Rio Grande do Sul. Uma onda patriótica tomou conta do Império. A população do Rio de Janeiro ocupou as ruas e depredou várias lojas pertencentes aos ingleses.

Em Paris, a comunidade brasileira, formada principalmente por estudantes, acompanhava em êxtase os acontecimentos. Pedro Américo, provavelmente também motivado pelo auxílio que recebera do agora ministro dos Negócios Estrangeiros, Antônio Coelho de Sá e Albuquerque, encabeçou protestos e resolveu escrever um documento em francês defendendo as posições do Brasil.

Esse panfleto seria enviado ao ministro Antônio Coelho de Sá e Albuquerque e publicado nos jornais da França. Provavelmente por não ter ainda o prestígio que almejava, o documento foi entregue à embaixada brasileira em Paris e terminou não tendo a divulgação e repercussão que Pedro Américo esperava. Não consta que tenha aparecido em jornais.

No final de 1862, com apenas dezenove anos, Pedro Américo havia concluído seu curso na École des Beaux Arts. Ele não desejava retornar ao Brasil. Seu objetivo era continuar na Europa para aperfeiçoar seus conhecimentos e fazer carreira artística. Sem condições econômicas para manter-se no Velho Continente, Pedro Américo recorreu ao imperador D. Pedro II, com o objetivo de ter sua bolsa prorrogada. Mas teve seu pedido negado. Foi obrigado a regressar ao Brasil.

\section{Império em Mutação}

Após atravessar o Atlântico e chegar ao Rio de Janeiro, Pedro Américo se deparou com um cenário nacional bastante dinâmico. O Brasil alcançara a posição de maior exportador de café do mundo. As primeiras linhas férreas implantadas no país interligavam as regiões cafeeiras do Vale do Paraíba e São Paulo aos portos do Rio de Janeiro e Santos ${ }^{21}$.

As elites provinciais estavam, definitivamente, subordinadas ao poder centralizador do Império. Jovens poetas, artistas e literatos buscavam construir uma identidade exclusiva para o país. Nos campos da política e da arte, nacionalismo e Romantismo se misturavam e expressavam num único projeto de sociedade.

${ }^{21}$ GRAHAM, Richard. "O Brasil de meados do século XIX à Guerra do Paraguai". In: BETHELL, História da América..., p. 771-825. 
Os filhos da elite agrária, que estudavam na Europa, estavam atualizados com os últimos acontecimentos do mundo intelectual. Na segunda metade do século XIX, o Ocidente vivenciava o auge do Romantismo. Movimento artístico, político, filosófico e cultural surgido na Europa no final do século XVIII, o Romantismo desenvolveu diferentes características no decorrer do século XIX. Em várias regiões do continente europeu, se posicionou contra o racionalismo e o iluminismo, exaltando o individualismo e o sentimentalismo. Em muitos países, serviu de base cultural para a consolidação do nacionalismo em ascensão.

Genericamente, o Romantismo artístico se baseia no culto ao sonho e a fantasia. Exalta o desempenho artístico do indivíduo, que tem o dom de captar a força dos elementos populares e a pujança da natureza. A fé, a paixão, o ideal político, a beleza da mulher, os feitos heroicos e as realizações históricas são os elementos constitutivos do amplo e profundo movimento romântico que abalou as estruturas do Antigo Regime e inspirou milhares de jovens a lutar, matar e morrer por seus ideais ${ }^{22}$.

No Brasil, o Romantismo adquiriu características próprias. Logo após a independência, jovens intelectuais incorporaram os princípios românticos e os adaptaram à realidade do país. Esses jovens eram membros da "boa sociedade", formada pela elite dos proprietários rurais, grandes comerciantes, clérigos, advogados, médicos e engenheiros. No âmbito político, não desejavam uma transformação profunda da sociedade escravista e latifundiária. Eles almejavam estabelecer uma Monarquia Constitucional, baseada nos preceitos políticos e econômicos do liberalismo ${ }^{23}$.

Em 1833, um grupo de estudantes reunidos em Paris decidiu dar início à renovação da literatura brasileira, no intuito de forjar uma identidade cultural própria. Influenciados pelo Romantismo francês, fundaram a Nitheroy - Revista Brasiliense, lançada em 1836. Seu lema era "Tudo pelo Brasil e para o Brasil". A revista só teve dois números, mas foi o suficiente para lançar os alicerces do Romantismo no país.

Esse grupo era formado, entre outros, por Domingos José Gonçalves Magalhães, Sales Torres Homem e Manuel de Araújo Porto Alegre. Nesse mesmo ano, Gonçalves Magalhães publicou o livro de poemas Suspiros poéticos de saudades, considerada a obra iniciadora do Romantismo no Império. E Araújo Porto Alegre viria a ser, como já mencionado, presidente da Academia Imperial de Belas Artes e mentor intelectual de Pedro Américo, além de seu sogro.

Para criar uma unidade nacional que agregasse as diversas províncias, os primeiros românticos buscaram exaltar os fatos históricos e a exuberante natureza existente no Brasil. No projeto de nação que ambicionavam edificar, o passado era glorioso $e$ o futuro seria brilhante, sem rupturas com o presente. Só que eles se depararam com um problema de difícil solução. Seria necessária a escolha de um símbolo nativista de amplitude nacional ${ }^{24}$.

Como louvar um passado em que os negros eram a principal força de trabalho $e$ se rebelaram sistematicamente contra o regime escravista? Como ressaltar os valores

\footnotetext{
${ }^{22}$ NUNES, Benedito. "A visão romântica". In: GUINSBURG, Romantismo, p. 13-21.

${ }^{23}$ CANDIDO, Antonio. Formação da literatura brasileira - Vol. 2. Belo Horizonte; Rio de Janeiro: Itatiaia, 1993, p. 11-38.

${ }^{24}$ AMORA, Antônio Soares. O romantismo. São Paulo: Cultrix, 1977, p. 75-119.
}

SAECULUM - Revista de História [37]; João Pessoa, jul./ dez. 2017. 
da tradição africana se a escravidão ainda era exercida em todo o Império? A solução foi buscar no índio o símbolo nativista da integração étnica e cultural. A população ameríndia, reduzida por doenças e guerras, não mais representava uma ameaça ao status quo. Sendo assim, a interpretação de um indígena idealizado, pacífico e cortês, deu embasamento ao movimento intelectual e artístico denominado Indianismo.

Mas os românticos enfrentaram alguma resistência por parte do establishment intelectual encastelado nas instituições oficiais. Até a década de cinquenta do século dezenove, os índios brasileiros eram retratados pejorativamente como bárbaros $e$ selvagens. O livro que foi premiado em 1843 pelo Instituto Histórico e Geográfico Brasileiro (IHGB), Como se deve escrever a História do Brasil, do naturalista alemão Karl Von Martius, é um exemplo do registro histórico da participação do indígena na formação do Brasil. Nesse trabalho, o índio é apresentado como responsável pelo atraso do processo civilizatório trazido pelos portugueses.

Outro historiador de renome na época, Francisco Rodolpho de Varnhagen, autor do livro História Geral do Brasil, publicado entre 1854 e 1857, também aponta os indígenas como figuras quase animalescas. Para Varnhagen, a história do Brasil só começa, de fato, a partir da chegada dos portugueses em 1500.

A interpretação sobre o papel do índio na história do país começou a ser alterada com o poeta e historiador Domingos Gonçalves de Magalhães. Nascido no Rio de Janeiro, em 1811, Domingos Gonçalves formou-se em medicina, mas foi através das letras que se destacou no cenário nacional. Foi diplomata, político, professor $e$ ensaísta. Primeiro intelectual brasileiro a se debruçar e valorizar o papel do índio na história do Brasil, ele foi um dos fundadores do Romantismo brasileiro e erigiu o indígena como símbolo da brasilidade.

Seus livros A Confederação dos Tamoios, publicado em 1856, e Os Indígenas Perante a História, lançado em 1860, são marcos importantes na defesa intransigente da contribuição dos povos indígenas na formação da nação. A partir dos escritos de Gonçalves Magalhães, o Romantismo brasileiro passou a ter uma fundamentação histórica no processo de mitificação e idealização do índio. O imperador D. Pedro II, de tão entusiasmado com os rumos do Romantismo no país, passou a estudar TupiGuarani e distribuir títulos nobiliárquicos com nomes indígenas.

Mas será no campo da literatura ficcional que o Indianismo alcançará seu apogeu. A partir da segunda metade do século XIX, a imagem do índio se assemelhará ao nobre medieval europeu nas construções ideológicas de honra, altivez, heroísmo $e$ cavalheirismo. Gonçalves Dias, com o livro Timbiras (1857), e José de Alencar, com os romances O Guarani (1857) e Iracema (1865), são expressões máximas dessa construção idealizada do índio brasileiro. Pedro Américo, leitor voraz desses livros, será influenciado pelo Romantismo e desenvolverá, em suas obras literárias, filosóficas e, principalmente, artísticas, um forte vínculo com o Romantismo.

Em 1872, Pedro Américo também rendeu homenagem ao Indianismo através da pintura. Num quadro de pequenas dimensões $(22,5 \times 28 \mathrm{~cm})$ e utilizando a técnica de óleo sobre madeira, ele pintou Moema, personagem trágico do poema épico Caramuru, escrito pelo frei Santa Rita Durão e publicado em 1781. Essa tela, pouco conhecida, não tem a mesma força e vigor de outras obras. Mas serve para demonstrar o engajamento de Pedro Américo na valorização do elemento indígena na formação da nação brasileira. 


\section{Ascensão de Pedro Américo}

Assim que chegou ao Brasil, em setembro de 1864, Pedro Américo percebeu que precisava se integrar imediatamente ao meio intelectual do Rio de Janeiro. Para que isso ocorresse em curto período de tempo, seria necessário ter seu nome reconhecido na Corte.

Possuindo uma grande bagagem cultural adquirida na Europa em anos de estudos, Pedro Américo deu início à publicação de uma série de artigos no jornal carioca Correio Mercantil. Divididos em 20 ediçóes e publicados entre 30 de setembro e 28 de dezembro de 1864, esses textos, inicialmente redigidos em Paris, expressavam sua concepção filosófica sobre a importância das artes na sociedade.

Os artigos, ainda manuscritos, foram reunidos num único exemplar e remetidos ao imperador. Na dedicatória que fez ao monarca, datado de 6 de janeiro de 1865, Pedro Américo escreveu: "Aceitai-o, pois, Senhor, não como uma oferta pretensiosa de mérito, mas como simples e mesquinha prova do meu reconhecimento pelos numerosos e incessantes favores que de Vossa Majestade tenho recebido" 25 . Através de nota, Pedro Américo reconhecia o papel fundamental que o imperador teve na sua formação intelectual.

O objetivo de Pedro Américo era evidente: demonstrar ao monarca que não só aprofundara os conhecimentos sobre pintura, como também desenvolvera as habilidades filosóficas ao analisar o papel das artes em sua relação com a história. Só em 1882 é que Pedro Américo transformou esses escritos em livro. Sua edição sairá em Florença, sob o título de Estudos Filosóficos Sobre as Belas Artes na Antiguidade. Com rigor filosófico e perfeccionismo na escrita, sem sombra de dúvida, esse livro é o que melhor sintetiza e revela a concepção intelectual de Pedro Américo.

Nessa obra, Pedro Américo demonstra paixão pela antiguidade clássica e sua interpretação do Romantismo. Nos artigos, vai realizando um balanço histórico da evolução cultural de diversas civilizações. As artes entre os egípcios, indianos, fenícios, assírios, persas, romanos e, finalmente, os gregos, são objetos das suas reflexões filosóficas e históricas. Mesmo apresentando uma visão idealizada do passado, característica inerente ao Romantismo, Pedro Américo faz uma busca na civilização grega dos elementos necessários à edificação do presente.

Seus textos têm motivação clara: respaldar as artes como elemento principal na consolidação de um projeto civilizacional liderado por um poder centralizador. $\mathrm{O}$ Romantismo que ele segue é aquele mesmo defendido pelos intelectuais brasileiros que fundaram a Revista Nitheroy em 1836: há a necessidade da institucionalização da cultura e o Estado forte e centralizado deve apoiá-la explicitamente.

Através de seus textos, Pedro Américo também está dialogando com o processo histórico da segunda metade do século XIX. Para ele, cabe ao artista desempenhar o papel principal na edificação de um projeto de nação. Pedro Américo defende a tese de que a arte tem um caráter pedagógico na formação de uma identidade nacional. Sua conclusão é óbvia: sem a valorização governamental das artes, o Brasil não se tornará uma nação civilizada. Sem o artista, o país estará condenado à barbárie.

\footnotetext{
${ }^{25}$ MELO, Pedro Américo de Figueiredo e. Considerações filosóficas sobre as belas-artes entre os antigos.
} João Pessoa: Ed. Universitária/ UFPB, 2006, p. 8. 
Pedro Américo demonstra estar imbuído de um sentimento muito caro ao Romantismo do século XIX: a ideia de um gênio. Seria aquele personagem, seja político, guerreiro ou artista que, em determinada conjuntura histórica, sintetiza os anseios da época e conduz a nação rumo à civilização, a exemplos de Alexandre na Grécia e Michelangelo na Itália. No caso brasileiro, esse papel caberia ao imperador D. Pedro II.

Sua fixação intelectual no renascentista Michelangelo e suas referências laudatórias ao imperador Pedro II são reveladoras dessa concepção. O jovem Pedro Américo, empolgado pelos conhecimentos adquiridos e desejando ter papel de destaque na pintura histórica, ansiava participar do processo artístico de concepção de nação.

O Romantismo expresso por Pedro Américo guarda particularidades com a sua formação e, principalmente, com seus anseios artísticos e sociais. Para alguns artistas europeus, o Romantismo era uma bandeira de contestação ao capitalismo em expansão, exaltando os valores medievais ${ }^{26}$.

No caso de Pedro Américo, o Romantismo que seguirá tinha um cunho nacionalista e conservador ${ }^{27}$. É o mesmo professado por seu mentor Manuel de Araújo Porto Alegre: nacionalista, influenciado pelo pensamento cristão, valorização do povo indígena, exaltação da natureza exuberante, patriotismo e, principalmente, atrelamento absoluto ao projeto de nação centrado na figura do imperador $\mathrm{D}$. Pedro II. No decorrer da sua produção intelectual e pictórica, até a proclamação da República, esses foram os temas abordados em suas pinturas e escritos.

Ao chegar ao Brasil, e por determinação do Imperador, Pedro Américo se submeteu ao concurso de professor da cadeira de Desenho Figurado, na Escola Imperial de Belas Artes. As provas do concurso foram extremamente rigorosas. A primeira delas consistia em executar, na presença de examinadores e num prazo de doze horas, a cópia de um modelo vivo. A segunda etapa era reproduzir, minuciosamente, o conjunto de músculos designado pela banca de professores. A terceira e última prova seria a mais complexa. O candidato teria um prazo de cinquenta dias para pintar uma tela a partir dos temas designados pelos examinadores.

Os seis assuntos apresentados aos candidatos foram os seguintes: Moisés salvo das águas; O filho pródigo retornando à casa do pai, Sócrates afastando Alcebíades do vício, Jacó recebendo as vestes ensanguentadas de José, Aquiles entregando Briseida aos Emissários de Agamenon e Agamenon retornando a seu palácio e sendo assassinado por Egisto. Todos os temas eram cenas bíblicas ou da mitologia grega.

Transcorrido o prazo regulamentar para a composição da obra, a banca composta por dez professores deu o veredito de quem seria o próximo professor da disciplina Desenho Figurado: Pedro Américo recebeu nove dos dez votos. Em 4 de fevereiro de 1866, saiu a nomeação de Pedro Américo para ocupar o cargo de professor titular da Academia Imperial de Belas Artes.

Após a nomeação para a Academia, a relação entre Pedro Américo e D. Pedro II estremeceu-se. Pedro Américo havia cedido à determinação do imperador e prestara o concurso, mas não abandonara o desejo de voltar imediatamente ao Velho

\footnotetext{
${ }^{26}$ SAYRE e\& LÖWY, Romantismo e política, p. 9-79.

${ }^{27}$ ROMANO, Roberto. Conservadorismo romântico. São Paulo: Editora da UNESP, 1997, p. 67-127.
} 
Continente. Logo em seguida a sua nomeação, ele solicitou uma licença para retornar à França.

O imperador queria que Pedro Américo permanecesse no Brasil, lecionando e formando novos pintores dentro dos princípios do nacionalismo em desenvolvimento. Depois de negociações que foram intermediadas pelo marquês de Olinda, D. Pedro II, mais uma vez, cedeu ao pedido de Pedro Américo. Ele teve a autorização para viajar ao continente europeu. Mas desta vez sem remuneração.

\section{Consagração Artística: Quadro 'Batalha de Campo Grande'}

Após sua segunda temporada na Europa, período em que Pedro Américo percorreu diversos países e concluiu o doutorado em Bruxelas, capital da Bélgica, ele regressou ao Brasil. Com a vitória na Guerra do Paraguai em 1870, uma onda nacionalista e de euforia patriótica tomou conta do império. Ao retornar à Corte, Pedro Américo começou a estabelecer uma rede de contatos com pessoas influentes ${ }^{28}$.

Pedro Américo sabia que, para se consolidar artisticamente na capital, teria que contar com o apoio explícito do imperador. Como a relação entre eles andava abalada por sua relutância em retornar ao Brasil, um encontro entre os dois teria que acontecer o mais breve possível para que o clima de tensão existente se desanuviasse.

No dia 22 de março de 1870, três semanas após o término da Guerra do Paraguai, Pedro Américo teve a oportunidade que esperava. Fora convidado pela direção da Academia Imperial de Belas Artes para ministrar a aula inaugural do curso de Estética e História da Arte. Como o imperador comunicou que se faria presente, ele poderia falar diretamente para D. Pedro II e a cúpula do governo.

$\mathrm{O}$ agora professor Pedro Américo, aproveitando o momento e embalado pelo clima patriótico reinante no Império, fez um pronunciamento exaltando o nacionalismo brasileiro. Preocupado com seu futuro artístico, fez referência aos artistas como profetas da civilização, envolvidos nas batalhas do progresso. Para Pedro Américo, a vitória na guerra da Tríplice Aliança inaugurava uma nova era de prosperidade e os obreiros das artes teriam um papel fundamental nessa etapa de desenvolvimento social e intelectual ${ }^{29}$.

Poucos dias depois da palestra, Pedro Américo deu mais um passo na aproximação com a família real. Motivado pelo senso de oportunidade que lhe era característico, entrou em contato com a princesa Isabel, filha e sucessora de D. Pedro II. Seu objetivo era pintar um quadro que retratasse a batalha de Campo Grande ${ }^{30}$.

Nesse painel, o conde D'Eu, esposo da princesa Isabel, seria a figura principal. Prontamente a princesa concordou, principalmente porque seu marido havia saído muito desgastado psicologicamente do conflito. O próprio conde D'Eu, em carta a seu pai, o duque de Nemours, escreveu: "A Guerra do Paraguai [...] me devastou

\footnotetext{
${ }^{28}$ ZACCARA, Pedro Américo...

${ }^{29}$ MELO, Pedro Américo de Figueiredo. Discursos. Florença: Imprensa de L'Arte della Stampa, 1888.

${ }^{30}$ CHRISTO, Maraliz de Castro Vieira. "Quando subordinados roubam a cena: 'A Batalha de Campo Grande' de Pedro Américo”. Sæculum - Revista de História, João Pessoa, n. 19, jul./dez. 2008, p. 81101.
} 
intelectualmente e criou em mim uma repugnância invencível por qualquer atividade ou trabalho prolongado" 31 .

A depressão que atingira o conde D'Eu, em decorrência da guerra, prejudicava politicamente a imagem da monarquia. Uma tela que exaltasse os "feitos heroicos" do genro do imperador seria extremamente importante para a recuperação da sua autoestima e, consequentemente, para a manutenção do poder e prestígio da família real.

Com a aquiescência da princesa Isabel, Pedro Américo encontrou uma excelente oportunidade para demonstrar sua competência artística. Prontamente começou a trabalhar na confecção do imenso painel. Ele não desejava fazer uma tela que retratasse a guerra de forma idealizada. Não queria compor um quadro com uma visão geral do conflito. Estava decidido a fazer uma pintura que retratasse o feito patriótico individual, colocando em primeiro plano o conde D'Eu como herói, o que havia sido amplamente divulgado pela imprensa da Corte, logo depois da batalha ter ocorrido.

De acordo com reportagens publicadas nos dias 15 e 16 de setembro de 1869, que versavam sobre a batalha de Campo Grande, o conde D'Eu havia se lançado contra os paraguaios no fragor do combate. Temendo por sua vida, o capitão Almeida Castro segurou as rédeas do seu cavalo, evitando assim seu avanço precipitado sobre as tropas inimigas. Indignado com a ação, imediatamente o conde D'Eu deu ordem de prisão ao capitão. Esse fato, nunca desmentido por testemunhas oculares, era a cena ideal de heroísmo que Pedro Américo resolvera imortalizar através de uma pintura histórica.

Decidido a se dedicar em tempo integral à pintura do quadro, Pedro Américo alega, em documento enviado à diretoria da Academia Imperial de Belas Artes, que está doente e cancela a disciplina Desenho Figurado, que estava ministrando. Lecionar nunca foi o seu principal objetivo profissional. Ele tinha a consciência que o resultado da tela seria fundamental para sua ascensão artística e social. No seu entender, precisava concentrar toda sua energia na confecção desse trabalho.

Detalhista ao extremo, Pedro Américo iniciou uma troca de correspondência com os oficiais que participaram da batalha de Campo Grande ao lado do conde D'Eu. Há, no Museu Imperial de Petrópolis, três cartas dos militares consultados: a do capitão Almeida Torres, datada de 20 de dezembro de 1869. Uma segunda, de autoria do engenheiro militar Alfredo d'Escragnolle Taunay, enviada do front em 22 de dezembro do mesmo ano. E a última, de 24 de fevereiro de 1870, escrita pelo capitão Almeida Castro, protagonista, junto com o conde D'Eu, da cena que seria retratada no painel ${ }^{32}$.

Das três cartas, a do capitão Almeida Castro é a mais precisa. Respondendo às indagações de Pedro Américo, o capitão Castro é minucioso na narração dos fatos. Descreve a farda e o chapéu que o conde D'Eu usava no dia da batalha, o tipo de esporas, o uniforme dos soldados e dos oficiais, as cores e o tamanho da crina do cavalo. E, de maneira emocionada e sucinta, revela o momento trágico no campo de

${ }^{31}$ IZECKSOHN, Victor. "Inferno na serra". Revista Nossa História, ano 3, n. 31, mai. 2006, p. 38.

32 TAUNAY, Visconde de. A campanha da Cordilheira: Diário do Exército. São Paulo: Editora Companhia Melhoramentos, 1926, p. 198-199. 
batalha. "Vários cadáveres nossos e muitos do inimigo, bem como cavalos mortos, alguns dos quais ainda encilhados" ${ }^{33}$. Inegavelmente sua análise influenciou a interpretação do artista.

Não sem conflitos se deu essa correspondência entre Pedro Américo e os oficiais consultados. Nessas cartas, os militares sugeriram outros episódios mais condizentes com o heroísmo patriótico. A cena de um oficial segurando a rédea do cavalo para deter o seu comandante não era a mais prestigiosa para os combatentes. Significava imprudência do conde D'Eu e indisciplina do capitão Almeida Castro.

Esses oficiais consultados não haviam compreendido o objetivo político da pintura. Ao retratar o conde D'Eu num arroubo de coragem, fato que realmente aconteceu, Pedro Américo construía uma imagem positiva de heroísmo individual, típico do Romantismo, suficiente para melhorar a imagem do conde D'Eu perante a sociedade, ao mesmo tempo em que exaltava a força e determinação da monarquia. E assim o fez.

Pedro Américo se demonstrava resoluto em construir sua carreira. Paralelamente à pintura da Batalha de Campo Grande, deu início pela imprensa a uma bem urdida campanha de divulgação da tela ainda em elaboração. Em 15 de junho de 1870, Ladislau Netto, diretor do Museu Nacional e amigo de Pedro Américo, publicou um artigo no Jornal do Commercio, exaltando as qualidades artísticas do quadro. Como o painel ainda não havia sido iniciado, estando apenas nos estudos preliminares, o artigo suscitou curiosidade e desconfiança sobre as habilidades de Pedro Américo.

Durante vários meses, a imprensa carioca cantou loas à pintura Batalha de Campo Grande. Nunca antes uma tela, que ainda não estava concluída, havia recebido uma quantidade tão grande de comentários elogiosos. A intenção de Pedro Américo era criar um clima favorável ao seu trabalho. Isso não era motivado apenas pela busca de reconhecimento artístico. A forte campanha publicitária desencadeada também tinha outro objetivo.

A polêmica sobre o quadro Batalha de Campo Grande chegou até o plenário do Congresso Imperial. Na sessão ocorrida em 28 de agosto de 1871, os deputados Francisco Gomes da Silva, representante do Rio Grande do Norte, e Luís Carlos Fonseca, eleito pela província de Minas Gerais, propuseram que o painel fosse adquirido pelo governo imperial.

Fato interessante é que, quando Pedro Américo apresentou a proposta a princesa Isabel de realizar o quadro sobre o conde D'Eu, nada ficou acertado sobre a quantia que ele receberia pelo trabalho. Em consequência disso, Pedro Américo articulou para que seus amigos, através dos jornais, exaltassem o valor artístico e histórico da tela, com o intuito de "sensibilizar" a família Real para que pagasse por seu trabalho. Em pouco tempo, o governo imperial se viu pressionado. Vários jornais do país faziam apelos para que o governo imperial adquirisse a obra.

Paralelamente à polêmica em torno da tela, Pedro Américo continuou na trajetória de construir uma imagem de "gênio nacional das artes". Com apenas 28 anos e sem nenhum trabalho artístico relevante, teve sua biografia publicada em 1871. Escrita pelo poeta e jornalista Luiz Guimarães Júnior, seu colega da época em que estudou

${ }^{33}$ MACHADO, Vladimir. "1871: a fotografia na pintura da batalha de Campo Grande de Pedro Américo". Revista 19\&20, Rio de Janeiro, vol. II, n. 3, jul. 2007, p. 7. 
no Colégio Pedro II, a biografia precoce faz uma síntese épica e elogiosa da trajetória de Pedro Américo. Desde sua infância pobre no interior da Paraíba, passando pela França e Bélgica, até chegar ao apogeu. De acordo com Luiz Guimarães, Pedro Américo era um fenômeno da pintura histórica ${ }^{34}$.

As primeiras críticas que Pedro Américo recebeu pela imprensa ocorreram no ano de 1870 e não ficaram restritas ao seu talento artístico. Em diversos artigos, apareceram questionamentos sobre a veracidade da sua titulação de doutorado. Em algumas matérias anônimas, seus detratores faziam ilações de que ele havia comprado o título de doutor. Pedro Américo, de personalidade forte e orgulhoso dos seus estudos e titulação, escreveu para a Universidade de Bruxelas solicitando a confirmação do seu doutoramento.

Em carta datada de 30 de setembro de 1870, publicado no Jornal do Commercio, o diretor da Universidade de Bruxelas, professor Guillaume Tiberghien, confirmou que ele havia obtido o título de doutor seguindo todos os trâmites acadêmicos $e$ legais. No final da carta diz:

Indignou-me verdadeiramente o ver de maneira por que em alguns jornais brasileiros se tem falado, assim do seu livro, como do nosso ensino. Que vilipendiosa intriga! Terá porventura $V$. invejosos e nós inimigos no seu país? [...] Entretanto, se tornar a encontrar aí qualquer obstáculo inesperado, não se esqueça de que é adjunto à faculdade de ciências de nossa Universidade, e que, ipso facto, um lugar honroso lhe é reservado entre os membros do corpo acadêmico de Bruxelas, logo que V. queira voltar a carreira das ciências. ${ }^{35}$

Com essa carta, Pedro Américo encerrou a polêmica pública em torno do seu título de doutor em Ciências Naturais.

Mesmo com essa resposta, os contendores de Pedro Américo continuaram a publicar críticas, dessa vez condenando a campanha de promoção do seu trabalho. Ao longo do ano de 1871, Pedro Américo havia demonstrado rara habilidade para se promover com a publicação de sua biografia e artigos laudatórios em jornais. A partir dessa notoriedade, atraiu muitos adversários que o fustigavam como podiam. No Jornal O Guarani, em 2 de setembro de 1871, saiu matéria afirmando que uma análise de uma tela, ainda não terminada, não deveria se basear meramente na opinião de amigos.

A tela Batalha de Campo Grande também se tornou tema político. Dois notórios republicanos publicaram ensaios em defesa dessa obra. O primeiro trabalho foi editado por Quintino Bocaiuva, intitulado A Batalha de Campo Grande, Quadro Histórico. Nele, Bocaiuva ressalta os dotes artísticos de Pedro Américo. Bocaiuva foi um dos redatores do Manifesto Republicano, lançado em 3 de dezembro de 1870.

\footnotetext{
${ }^{34}$ GUIMARÃES JR, Luis. Perfil biographico de Pedro Américo. Rio de Janeiro: Brown \& Almeida Ed., 1871.

${ }^{35}$ AMÉRICO apud OLIVEIRA, Pedro Américo, sua vida..., p. 79. 
O outro ensaio publicado no mesmo sentido foi o de Otaviano Hudson, intitulado Pedro Américo: Descripção do Quadro Histórico da Batalha do Campo Grande. Fundador do Partido Republicano e opositor ardente do regime monárquico, o jornalista Otaviano Hudson comparava Pedro Américo ao pintor francês de batalhas Horace Vernet, de fama internacional.

No seu opúsculo, Otaviano Hudson apresentava Pedro Américo como um moço pobre e sem proteção, fazendo questão de esquecer a ajuda fundamental que ele recebera do imperador D. Pedro II. Para Hudson, Pedro Américo era um célebre pintor de batalhas, sendo um grande expoente das artes brasileiras, ao lado de José de Alencar, Gonçalves Dias, João Caetano, Carlos Gomes e Victor Meirelles.

Mas, na realidade, até aquele momento, Pedro Américo era apenas um jovem $e$ promissor professor de pintura, que ainda não havia finalizado nenhuma tela sobre batalhas. Através das páginas do jornal, o republicano Otaviano Hudson passou a fazer apelos para que o quadro fosse adquirido pelo governo imperial.

$\mathrm{Na}$ verdade, qual seria o interesse dos republicanos em alavancar a carreira de um pintor que notoriamente era protegido do imperador? Qual era o objetivo em colocálo num patamar de importância artística que ainda não possuía? Tanto Quintino Bocaiuva quanto Otaviano Hudson estavam desenvolvendo uma estratégia política muito nítida. Valorizar ao extremo um pintor ainda desconhecido, mas com um potencial artístico inegável, que se relacionava muito bem com os republicanos, mesmo que não pertencesse ao seu partido.

Para os republicanos, se houvesse uma projeção maior de Pedro Américo que ofuscasse o prestígio de Victor Meirelles, pintor consolidado e reconhecidamente vinculado à monarquia, haveria a abertura de uma fissura no meio intelectual e a causa republicana ganharia força. Pedro Américo estava ciente do seu papel político. Até o final do regime monárquico, soube muito bem se equilibrar entre os dois grupos. Tinha amigos entre monarquistas e republicanos. Só em 1889, com a deposição do seu protetor D. Pedro II, Pedro Américo assumiu seu republicanismo que, se existia, até então estava muito bem disfarçado.

Muitos desses republicanos eram membros do exército e viam, no quadro Batalha de Campo Grande, uma forma de valorização do papel que o exército havia desempenhado na Guerra do Paraguai. Quanto à posição política de Pedro Américo, se era monarquista ou republicano, ele conseguiu, na sua ascensão artística, manter a proteção de $\mathrm{D}$. Pedro II e a simpatia dos partidários do republicanismo.

Outro fato veio respaldar a obra de Pedro Américo. Como as telas alusivas a Guerra do Paraguai encomendadas ao pintor Victor Meirelles retratavam apenas os feitos heroicos da Marinha, membros da oficialidade do exército passaram a apoiar com entusiasmo a pintura Batalha de Campo Grande. Depois da mobilização de parte da imprensa, de deputados e membros do exército, finalmente o governo imperial cedeu. D. Pedro II terminou se curvando a pressão pública muito bem orquestrada por Pedro Américo. Em 28 de janeiro de 1872, o Ministro da Guerra, Barão de Jaguaribe, autorizou a aquisição do quadro por 13 contos de réis.

Em 6 de março de 1872, surgiu o momento para Pedro Américo apresentar seu painel. Nesse dia teve início a XXII Exposição Geral da Academia Imperial de Belas 
Artes. Foi o primeiro grande acontecimento cultural após o término da Guerra do Paraguai $e$ a exaltação dos feitos guerreiros dominou a tônica das telas.

Nos meses subsequentes, milhares de pessoas visitaram e puderam ver as obras apresentadas. Nessa oportunidade, a tela Batalha de Campo Grande foi apreciada por toda a Corte. Alguns protagonistas do fato não ficaram satisfeitos com o resultado. O capitão Taunay, que estava próximo do conde D'Eu no episódio, escreveu em suas memórias que a expressão facial que fora retratado não correspondia à verdade, pois Pedro Américo o havia pintado "com cara espantada, coisa que nunca tive em ocasiões de perigo, gabo-me disto" 36 .

O quadro tinha uma dimensão grandiosa. Óleo sobre tela, $332 \times 530 \mathrm{~cm}$. Apesar de retratar um momento crucial do conflito, sua análise revela vários elementos mais gerais da guerra. Movimentos de combate, a fúria dos golpes, o nervosismo dos cavalos $e$ as expressões de ódio, angústia e dor dos soldados estão registrados no grande painel. Os relatos dos participantes do conflito demonstram que a área onde ocorreu o embate era muito mais ampla, sendo esse o motivo que possibilitou o ataque da cavalaria contra o inimigo. A opção artística de Pedro Américo foi recriar a cena da batalha num ambiente mais compacto e dramático, de intenso e sangrento conflito ${ }^{37}$.

Há uma nítida mensagem nacionalista na tela. Os militares brasileiros foram retratados usando belas fardas azuis, representando a civilização. Enquanto isso, os soldados paraguaios, seminus, encarnavam a barbárie. Mesmo afirmando que queria ser fidedigno ao fato, Pedro Américo inseriu na obra um personagem que, segundo os relatos, não se encontrava no campo de batalha. Para render homenagem à Igreja Católica, Pedro Américo pintou o frade capuchinho Fidelis d'Ávola de frente para o espectador, cuidando dos soldados brasileiros feridos. Na verdade, o religioso não estava presente no campo de batalha.

Após meses de uma campanha exitosa nas páginas dos jornais por todo Império, Pedro Américo havia alcançado seu objetivo. Tornara-se, aos 28 anos, o artista mais conhecido do Brasil. Em consequência da polêmica envolvendo sua obra Batalha de Campo Grande, um grande número de pessoas visitou a exposição e admirou a grandiosidade da tela.

De acordo com o jornal O Mosquito, em edição de 13 de junho de 1872, mais de 60 mil pessoas compareceram a XXII Exposição Geral da Academia Imperial de Belas Artes do Rio de Janeiro. O escritor Machado de Assis, em carta publicada em 10 de Novembro de 1871, no jornal A Reforma, afirmou com precisão e poder de síntese: "Pedro Américo não pintou somente a sangrenta Batalha de Campo Grande, pintou sobretudo a vitória, que já ali se vê patente e decisiva" ${ }^{38}$.

\section{Considerações Finais}

A tela Batalha de Campo Grande foi seu primeiro trabalho de cunho nacionalista de ampla repercussão na Corte. Com ele, Pedro Américo alcançou notoriedade

\footnotetext{
${ }^{36}$ TAUNAY apud MACHADO, "1871: a fotografia...", p. 12

${ }^{37}$ TAUNAY, Visconde de. Memórias. São Paulo: Edições Melhoramento, s.d., p. 359.

${ }^{38}$ CHRISTO, "Quando subordinados...", p. 99.
} 
artística e prestígio social. Admirado por militares e aceito no seleto grupo de pintores palacianos, Pedro Américo deu início a uma exitosa carreira de pintor histórico de cunho romântico. Ao longo da sua trajetória, pintou diversos painéis exaltando a família real, altos funcionários da burocracia imperial e membros da elite agrária.

Pedro Américo era um homem do século XIX, longo período artístico marcado por lutas sociais, disputas ideológicas e construção da nacionalidade. $\mathrm{O}$ apoio que recebeu do monarca D. Pedro II impulsionou sua carreira artística e o projetou internacionalmente. Sua forte vinculação com o Império o marcou indelevelmente. Mesmo com a sua súbita adesão ao republicanismo, a partir de 1889, outros agentes políticos passaram a ocupar o cenário nacional. As grandes pinturas históricas, financiadas pelo Estado, foram sendo abandonadas.

Nos últimos anos de vida, mesmo acometido de uma cegueira parcial $e$ agravamento dos sintomas do beribéri, Pedro Américo continuava a exercer com afinco seu intenso trabalho artístico. Seu ateliê em Florença continuava sendo visitado por várias pessoas que iam fazer encomendas. As obras O Noviciado, A Mulher de Putifar e A Primeira Culpa, quadros com um significativo teor sensual, foram aperfeiçoados. Muitas outras pinturas com temas religiosos foram confeccionadas. Em 7 de outubro de 1905, aos 61 anos, Pedro Américo faleceu em plena atividade artística fazendo o que mais gostava: pintar.

\section{$\operatorname{soc} 2$}

\section{RESUMO}

As telas de Pedro Américo que retratam a Guerra do Paraguai (1864-1870) impressionam pela grandiosidade, perfeccionismo e impacto visual, além de contribuírem para o prestígio político do exército brasileiro. Por meio das suas pinturas históricas de cunho cívico, o nacionalismo forjado no Paço Imperial ganhou expressão artística, auxiliou a estruturar o Estado brasileiro e se cristalizou no imaginário popular. Seu quadro mais famoso, Proclamação da Independência, passou a fazer parte da formação cultural e política de várias gerações e é reconhecido por todos os brasileiros minimamente letrados.

Palavras Chave: Nacionalismo; Romantismo; Império Brasileiro.

\begin{abstract}
Pedro Americo's canvases portraying the Paraguayan War (1864-1870) overwhelm by the greatness, perfectionism and visual impact, besides contributing to the political prestige of the Brazilian Army. Through his historical paintings with civic hallmarks, the nationalism forged in the Imperial Palace won artistic expression, assisted the structuring of the Brazilian State and crystallized into the popular imagery. His most famous painting, Proclamation of Independence, came out to take part in the political and cultural formation of several generations and it is acknowledged by all Brazilians minimally literate.
\end{abstract}

Keywords: Nationalism; Romanticism; Brazilian Empire.

Artigo recebido em 15 ago. 2017.

Aprovado em 29 out. 2017. 